\title{
X-Ray and NMR study of tetra- and penta-coordinated stanoxanes derived from trans-cinnamic acid
}

\author{
Ángel Ramos-Organillo,*a Claudia Rubí Guzmán-Tiburcio, ${ }^{\text {a }}$ \\ Ana Mirna Flores-Bustamante, ${ }^{a}$ Adrián Peña-Hueso, ${ }^{b}$ Jorge Guerrero-Álvarez, \\ and Angelina Flores-Parrab \\ ${ }^{a}$ Facultad de Ciencias Químicas, Universidad de Colima, km 9 carretera Colima-Coquimatlán, \\ Coquimatlán, Colima. CP 28400 \\ ${ }^{b}$ Departamento de Química, Centro de Investigación y de Estudios Avanzados-IPN. Apartado \\ Postal 14-740. México 07000, D. F. México \\ ${ }^{c}$ Centro de Investigaciones Químicas, Universidad Autónoma del Estado de Morelos, Av. \\ Universidad 1001. Col. Chamilpa, Cuernavaca, Morelos. C. P. 62209. \\ E-mail: aaramos@ucol.mx
}

Contribution to Professor Rosalinda Contreras on the occasion of her $60^{\text {th }}$ anniversary

\begin{abstract}
We report a new stanoxano polymer structure 1, derived from trans-cinnamic acid and triphenyltin chloride. X-ray structure shows a carboxylated bridge between two tin groups in a linear rearrangement, the pack in the unit cell is conformed by non-classical interactions (D$\mathrm{H} \cdots \mathrm{A}$ ), because the presence of aromatic rings were observed $\mathrm{C}-\mathrm{H} \cdots \pi$ interacting in a supramolecular structure. In solution the compound 1 was compared with tributhyltin-transcinnamete 2, the NMR data shown penta- and tetra-coordinated compounds respectively, both compounds were dissolved in $\mathrm{DMSO}^{-} \mathrm{d}_{6}$ and the tin geometry goes from penta- to hexacoordinated for $\mathbf{1}$ and from tretracoordinated to pentacoordinated for $\mathbf{2}$.
\end{abstract}

Keywords: trans-Cinnamic acid, X-ray polymer structure, tin compounds

\section{Introduction}

trans-Cinnamic acid is found as structural unit in anti-oxidant compounds, in some drugs and balsams. ${ }^{1}$ It is a cinnamaldehyde derivative that comes from cinnamon, in the last ten years the cinnamic acid and its derivatives were found to be anti-bacterials, anti-fungals, and are important in the synthesis of cumarinic derivatives. ${ }^{2}$ The interest in organotin compounds is because their biological activity, ${ }^{3}$ so the understanding of the structural base needs special attention of the 
electronic effects and coordination number. It is well known the potential activity of tin compounds as anti-cancer and anti-tumor agents ${ }^{4}$ and the relationship between the organic fragment and organometallic tin plays an important role in some biological aspects, for example as nematicidal and insecticidal. ${ }^{5}$ The spectroscopic study of tetra- and pentacoordinated stanoxanes derived from trans-cinnamic acid; base their importance on their organic structure, because they are models of NMR and X-ray diffraction and biological assays.

\section{Results and Discussions}

Compounds 1 and $\mathbf{2}$ were obtained following the procedure shown in the Scheme 1, this is a variation of the Gielen ${ }^{6}$ method (see experimental section), and we use benzene as solvent because we need to avoid solvent coordination. Both compounds which are white solids, were obtained in good yields and they are stable to air and moisture. Then the compounds $\mathbf{1}$ and 2 were dissolved in DMSO- $\mathrm{d}_{6}$ to get compounds $\mathbf{3}$ and $\mathbf{4}$ also were analysed spectroscopically.

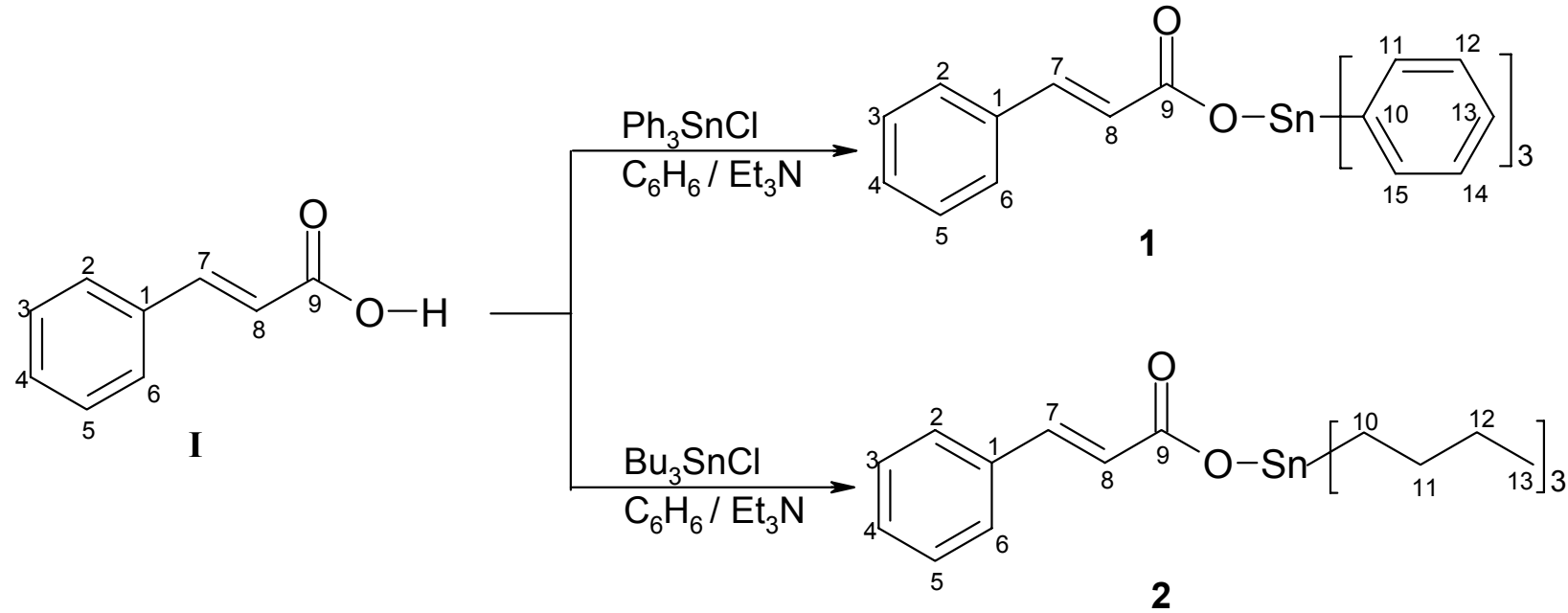

Scheme 1. Syntheses of complexes $\mathbf{1}$ and 2, and numerbering system used to analyse the spectrum.

\section{NMR Analyses}

All compounds have good spectra; and were corroborated with COSY and HETCOR experiments, tables 1 and 2, chemical shifts are characteristics of the respective coordination number in solution. ${ }^{7}$ The ${ }^{119} \mathrm{Sn}$ values in -112.0 for compound 1 with a $\Delta \delta=-64$ ppm with respect to the starting material $\mathrm{Ph}_{3} \mathrm{SnCl}^{8}$ and in +110.9 for compound 2 with a $\Delta \delta=-30 \mathrm{ppm}$ with respect to the starting material $\mathrm{Ph}_{3} \mathrm{SnCl}_{1}{ }^{9}$ are indicative of penta- and tetra-coordinated compounds, respectively. Danutsh ${ }^{10}$ et al. reported the ${ }^{119} \mathrm{Sn}$ chemical shift of $\mathrm{Me}_{3} \mathrm{Sn}-m-\mathrm{Me}-$ trans-cinnamate with ${ }^{119} \mathrm{Sn}=+129 \mathrm{ppm}$, that is close in value to compound 2 . A related 
carboxylic triphenyltin compound was reported by Holeček ${ }^{11}$ et al. $\mathrm{Ph}_{3} \mathrm{SnOC}(\mathrm{O}) \mathrm{Ph}$ with ${ }^{119} \mathrm{Sn}=$ 110 ppm and tributyltin compound by Davies ${ }^{8}$ et al. of $\mathrm{Bu}_{3} \mathrm{SnOC}(\mathrm{O}) \mathrm{C}_{6} \mathrm{H}_{4} \mathrm{OCOMe}-2$ with ${ }^{119} \mathrm{Sn}=$ $+115 \mathrm{ppm}$, both compounds corroborate the assignment of compounds $\mathbf{1}$ and $\mathbf{2}$. The acidity of $\mathbf{1}$ and 2 were evident when we added DMSO- $\mathrm{d}_{6}$ to obtain compounds 3 and $\mathbf{4}$, the chemical shifts change their value at lower frequency, $-260.2(\Delta \delta(\mathbf{1 - 3})=148 \mathrm{ppm})$ for $\mathbf{3}$ and -20.0 for $4(\Delta \delta(\mathbf{2}-\mathbf{4})$ $=131 \mathrm{ppm})$, it changes the geometry around the tin atom, so tin goes from pentacoordinated (compound 1) $\rightarrow$ hexacoordinated (compound 3) and from tetracoordinated (compound 2) $\rightarrow$ pentacoordinated (compound 4). (Scheme 2) When we analyzed the ${ }^{119} \mathrm{Sn}$ values of $\mathrm{Ph}_{3} \mathrm{SnCl}$ and $\mathrm{Ph}_{3} \mathrm{SnCl}\left(\mathrm{DMSO}-\mathrm{d}_{6}\right)$, the $\Delta \delta=181 \mathrm{ppm}$, we found the same behaviour, but different magnitude, that was found in compounds $\mathbf{1 - 4} .^{11,12}$<smiles>COC(=O)/C=C/c1ccccc1</smiles><smiles>O=C(/C=C/c1ccccc1)O[Sn](Br)(Br)Br</smiles><smiles>CCOC(=O)/C=C/c1ccccc1</smiles><smiles></smiles>

Scheme 2. Structure proposes of tetra-, penta- and hexa-coordinated compounds.

Because the trans-cinnamic acid and phenyl nuclei are not modified, the ${ }^{13} \mathrm{C}$ chemical shifts have not meaningful changes. The $\mathrm{C} 7$ position goes at lower frequency from starting material I to $\mathbf{1}(\Delta \delta=2.4), \mathbf{2}(\Delta \delta=3.4), \mathbf{3}(\Delta \delta=5.5)$ and $\mathbf{4}(\Delta \delta=6.0)$, the same behaviour was observed for C9 position but the $\Delta \delta$ values are smaller $(0.6,0.6,2.4,2.3$, respectively) than $\mathrm{C} 7$. The $\mathrm{C} 8$ signal is shifted to higher frequency from that in the starting material I to $\mathbf{1}(\Delta \delta=2.3), \mathbf{2}(\Delta \delta=3), \mathbf{3}$ $(\Delta \delta=56.4)$ and $4(\Delta \delta=6.6)$. All those changes are indicative in the compounds 1 and 2 of the presence of tin fragment; meanwhile the biggest changes for compounds $\mathbf{3}$ and $\mathbf{4}$ are indicative of 
the high coordination number in the tin atom.

Table 1. Chemical shits of ${ }^{119} \mathrm{Sn}$ and ${ }^{13} \mathrm{C}$, in $\mathrm{CDCl}_{3}$, in brackets are coupling constants ${ }^{\mathrm{n}} \mathrm{J}\left({ }^{13} \mathrm{C}-{ }^{117 / 119} \mathrm{Sn}\right)$

\begin{tabular}{cccccc}
\hline Comp. & $\mathbf{I}^{\mathbf{a}}$ & $\mathbf{1}^{\mathbf{a}}$ & $\mathbf{2}^{\mathbf{a}}$ & $\mathbf{3}^{\mathbf{b}}$ & $\mathbf{4}^{\mathbf{b}}$ \\
\hline${ }^{119} \mathrm{Sn}$ & -- & -112.0 & 110.9 & -260.2 & -20.0 \\
$\mathrm{C} 1$ & 134.1 & 135.0 & 137.2 & 135.5 & 135.7 \\
$\mathrm{C} 2$ & 128.4 & 129.9 & 128 & 129.9 & 128.1 \\
$\mathrm{C} 3$ & 129.0 & 128.4 & 128.8 & 128.2 & 129.3 \\
$\mathrm{C} 4$ & 130.7 & 128.8 & 129.8 & 128.2 & 129.7 \\
$\mathrm{C} 5$ & 129.0 & 128.4 & 128.8 & 128.2 & 129.3 \\
$\mathrm{C} 6$ & 128.4 & 129.9 & 128.0 & 129.9 & 128.1 \\
$\mathrm{C} 7$ & 147.1 & 144.7 & 143.7 & 141.6 & 141.1 \\
$\mathrm{C} 8$ & 117.4 & 119.7 & 120.4 & 123.8 & 124.0 \\
$\mathrm{C} 9$ & 172.8 & 173.4 & 172.2 & 170.4 & 170.5 \\
$\mathrm{C} 10$ & -- & 138.9 & 16.9 & 144.0 & 19.2 \\
& & $(\mathrm{NO})$ & $(\sim 351.9)$ & $(829)$ & $(475,454)$ \\
$\mathrm{C} 11$ & -- & 136.9 & 28.16 & 136.9 & 28.3 \\
& & $(\mathrm{NO})$ & $(19.8)$ & $(453)$ & $(26.9)$ \\
$\mathrm{C} 12$ & -- & 128.9 & 27.0 & 128.8 & 27.0 \\
& & $(63.3)$ & $(67.2)$ & $(69.2)$ & $(73.8)$ \\
$\mathrm{C} 13$ & -- & 130.1 & 13.99 & 129.3 & 14.2 \\
$\mathrm{C} 14$ & -- & 128.9 & -- & 128.8 & -- \\
$\mathrm{C} 15$ & -- & 136.9 & -- & 136.9 & -- \\
\hline
\end{tabular}

${ }^{\mathrm{a}} \mathrm{CDCl}_{3}{ }^{\mathrm{b}} \mathrm{DMSO}-\mathrm{d}_{6}$, NO not observed

The coupling constants ${ }^{\mathrm{n}} \mathrm{J}\left({ }^{13} \mathrm{C}-{ }^{117 / 119} \mathrm{Sn}\right)$ that are in brackets in Table 1 correspond to assigned atom and all of them are indicative of the tin geometry, according to the literature. ${ }^{13}$

The ${ }^{1} \mathrm{H}$ NMR for compounds $\mathbf{1 - 4}$ are summarized in Table 2, the H7 signals for different compounds are shifted to lower frequency than the starting material I, while H8 almost does not have changes. The rest of the protons have not important changes. The trans- coupling constant ${ }^{3} \mathrm{~J}\left({ }^{1} \mathrm{H} 7-{ }^{1} \mathrm{H} 8\right)$ was confirmed in all compounds around $16 \mathrm{~Hz}$ for phenyltin- derivatives and $15 \mathrm{~Hz}$ for butyltin- derivatives, all of them are close to starting material $\mathbf{I}$. 
Table 2. Chemical shifts $\left(\delta\right.$, ppm) of ${ }^{1} \mathrm{H}$ for compounds 1-4, The coupling constant ${ }^{3} \mathrm{~J}\left({ }^{1} \mathrm{H}-{ }^{1} \mathrm{H}\right)$ trans is showing between parenthesis $(\mathrm{Hz})$

\begin{tabular}{cccccc}
\hline Comp. & $\mathbf{I}^{\mathbf{a}}$ & $\mathbf{1}^{\mathbf{a}}$ & $\mathbf{2}^{\mathbf{a}}$ & $\mathbf{3}^{\mathbf{b}}$ & $\mathbf{4}^{\mathbf{b}}$ \\
\hline $\mathrm{H} 2$ & 7.56 & 7.92 & 7.43 & 7.31 & 7.55 \\
$\mathrm{H} 3$ & 7.40 & 7.55 & 7.27 & 7.56 & 7.33 \\
$\mathrm{H} 4$ & 7.42 & 7.54 & 7.27 & 7.56 & 7.33 \\
$\mathrm{H} 5$ & 7.40 & 7.55 & 7.27 & 7.56 & 7.33 \\
$\mathrm{H} 6$ & 7.56 & 7.92 & 7.43 & 7.31 & 7.55 \\
H7 & $7.81(16.1)$ & $7.81(15.6)$ & $7.55(16.0)$ & $7.37(16.1)$ & $7.37(15.1)$ \\
$\mathrm{H} 8$ & $6.46(16.1)$ & $6.65(15.6)$ & $6.44(16.0)$ & $6.46(16.1)$ & $6.42(15.1)$ \\
$\mathrm{H} 10$ & -- & -- & 1.25 & -- & 1.12 \\
$\mathrm{H} 11$ & -- & 7.44 & 1.57 & 7.88 & 1.59 \\
$\mathrm{H} 12$ & -- & 7.41 & 1.25 & 7.45 & 1.30 \\
$\mathrm{H} 13$ & -- & 7.40 & 0.84 & 7.43 & 0.85 \\
$\mathrm{H} 14$ & -- & 7.41 & -- & 7.45 & -- \\
$\mathrm{H} 15$ & -- & 7.44 & -- & 7.88 & -- \\
\hline${ }^{\mathrm{a}} \mathrm{CDCl}_{3}{ }^{\mathrm{b}}{ }^{\mathrm{DMSO}-\mathrm{d}_{6}}$ & & & &
\end{tabular}

\section{X-Ray analyses}

Compound 1 crystallizes in the monoclinic space group $\mathrm{P} 2_{1} / \mathrm{n}$ from chloroform, the crystal data, selected bonds and angles are given in Tables 3, 4. Figure 1 shows the ORTEP diagram, three phenyl groups in a equatorial position and trans-cinnamic acid is occupying axial position, in the opposite site, from this, an empty space shows coordination to the tin atom by other electron donor group.

In the lattice, (Figure 2) two triphenyltin groups are bridged by carboxylic group of transcinnamic acid, with two different distances $\mathrm{d}(\mathrm{O} 1-\mathrm{Sn} 1)=2.275(2) \AA$ and $\mathrm{d}(\mathrm{O} 2-\mathrm{Sn} 1)=2.230(2) \AA$ with the angle $(\mathrm{O} 1-\mathrm{Sn} 1-\mathrm{O} 2)=172.30(7)^{\circ}$, making a polymeric rearrangement where tin atom is in trigonal bipyramidal (BPT) geometry.

The net shows, Figures 2 and 3, that crystal packing is structured by non-classical hydrogen bonds $(\mathrm{C}-\mathrm{H} \cdots \mathrm{A})$ related to $(\mathrm{C}-\mathrm{H} \cdots \pi)$ interactions as soft acid and soft base ${ }^{14 \mathrm{a}}$. In Table 5 are listed the hydrogen contacts geometries. In the Figure 2, C17-H17 is acting as a bifurcate donor because it is interacting with $\mathrm{O} 1^{*}$, as a true hydrogen bond ${ }^{14 \mathrm{~b}}$, and $\mathrm{C} 9^{*}$, against $\mathrm{C} 27-\mathrm{H} 17$ is acting as a normal donor group to $\mathrm{C} 15^{*}$ and $\mathrm{C} 15^{*}-\mathrm{H} 15^{*}$ is a normal donor of $\mathrm{C} 17 .{ }^{14 \mathrm{c}, \mathrm{d}}$ The individual interactions are not important; but they are essential to the supramolecular structure, so they manage the growing of the crystal packing, Figure 4. 
Table 3. The crystal data of compound 1

\begin{tabular}{|c|c|}
\hline Formula & $\mathrm{C} 27 \mathrm{H} 22 \mathrm{O} 2 \mathrm{Sn} 1$ \\
\hline Formula Weight & 497.16 \\
\hline Crystal System & Monoclinic \\
\hline Space group & P21/n, (No. 14) \\
\hline$\AA[\AA]$ & $12.8222(2)$ \\
\hline $\mathrm{b}[\AA]$ & $11.4892(2)$ \\
\hline c $[\AA]$ & $16.0870(3)$ \\
\hline$\alpha\left[^{\circ}\right]$ & 90 \\
\hline$\beta\left[^{\circ}\right]$ & 102.3586(7), \\
\hline$\gamma\left[{ }^{\circ}\right]$ & 90 \\
\hline $\mathrm{V}\left[\AA^{3}\right]$ & $2314.97(7)$ \\
\hline Z & 4 \\
\hline $\mathrm{D}(\mathrm{calc})\left[\mathrm{g} / \mathrm{cm}^{* * 3}\right]$ & 1.426 \\
\hline $\mathrm{Mu}(\mathrm{MoKa})[/ \mathrm{mm}]$ & 1.123 \\
\hline $\mathrm{F}(000)$ & 1000 \\
\hline Crystal Size [mm] & $0.08 \times 0.14 \times 0.20$ \\
\hline \multicolumn{2}{|l|}{ Data Collection } \\
\hline Temperature $(\mathrm{K})$ & 293 \\
\hline Radiation [Angstrom] & MoKa, 0.71070 \\
\hline Theta Min-Max [Deg] & $3.7,27.5$ \\
\hline Dataset & $-15: 15 ;-12: 14 ;-20: 20$ \\
\hline Tot., Uniq. Data, R(int) & $9337, \quad 5170,0.021$ \\
\hline $\begin{array}{l}\text { Observed data }[\mathrm{I}>3.0 \\
\text { sigma(I)] }\end{array}$ & 3457 \\
\hline \multicolumn{2}{|l|}{ Refinement } \\
\hline Nref, Npar & 3457,338 \\
\hline $\begin{array}{l}R, w R 2, S \\
w=0.2760 .696 \mathrm{E}-01\end{array}$ & $0.0257,0.1719,1.10$ \\
\hline $0.466 \mathrm{E}-01-0.871 \mathrm{E}-02$ & \\
\hline Max. and Av. Shift/Error & $0.00,0.00$ \\
\hline $\begin{array}{l}\text { Min. and Max. Resd. } \\
\text { Dens. [e/Ang^3] }\end{array}$ & $-0.35,0.62$ \\
\hline
\end{tabular}


Table 4. Selected bond distances and angles of compound 1

\begin{tabular}{|c|c|c|c|c|c|}
\hline Atoms & Distance $(\AA)$ & Atoms & Angle $\left(^{\circ}\right)$ & Atoms & Angle $\left(^{\circ}\right)$ \\
\hline $\mathrm{C} 1 \mathrm{C} 2$ & $1.396(6)$ & $\mathrm{C} 2 \mathrm{C} 1 \mathrm{C} 6$ & $117.9(4)$ & C10 Sn1 C16 & $119.88(12)$ \\
\hline $\mathrm{C} 1 \mathrm{C} 6$ & $1.379(6)$ & $\mathrm{C} 2 \mathrm{C} 1 \mathrm{C} 7$ & $118.7(4)$ & O1 Sn1 C22 & $92.23(10)$ \\
\hline $\mathrm{C} 1 \mathrm{C} 7$ & $1.466(5)$ & $\mathrm{C} 6 \mathrm{C} 1 \mathrm{C} 7$ & $123.4(4)$ & $\mathrm{O} 2 \mathrm{Sn} 1 \mathrm{C} 22$ & $92.03(10)$ \\
\hline $\mathrm{C} 2 \mathrm{C} 3$ & $1.382(8)$ & $\mathrm{C} 1 \mathrm{C} 2 \mathrm{C} 3$ & $120.5(6)$ & C10 Sn1 C22 & $117.67(12)$ \\
\hline $\mathrm{C} 3 \mathrm{C} 4$ & $1.360(10)$ & $\mathrm{C} 2 \mathrm{C} 3 \mathrm{C} 4$ & $120.7(6)$ & C16 Sn1 C22 & $122.45(11)$ \\
\hline $\mathrm{C} 4 \mathrm{C} 5$ & $1.365(10)$ & C3 C4 C5 & $119.5(5)$ & $\mathrm{C} 24 \mathrm{C} 25 \mathrm{C} 26$ & $119.8(4)$ \\
\hline $\mathrm{C} 5 \mathrm{C} 6$ & $1.383(7)$ & C4 C5 C6 & $120.8(7)$ & $\mathrm{C} 25 \mathrm{C} 26 \mathrm{C} 27$ & $120.5(4)$ \\
\hline $\mathrm{C} 7 \mathrm{C} 8$ & $1.306(5)$ & $\mathrm{C} 5 \mathrm{C} 6 \mathrm{C} 1$ & $120.7(6)$ & $\mathrm{C} 22 \mathrm{C} 27 \mathrm{C} 26$ & $120.8(4)$ \\
\hline C8 C9 & $1.476(4)$ & $\mathrm{C} 1 \mathrm{C} 7 \mathrm{C} 8$ & $128.4(4)$ & C9 O1 Sn1 & $138.00(18)$ \\
\hline $\mathrm{C} 9 \mathrm{O} 1$ & $1.257(3)$ & C7 C8 C9 & $123.3(3)$ & $\mathrm{Sn} 1 \mathrm{O} 2 \mathrm{C} 9$ & $140.1(2)$ \\
\hline $\mathrm{C} 9 \mathrm{O} 2$ & $1.263(3)$ & C8 C9 O1 & $119.9(3)$ & O1 Sn1 O2 & $172.30(7)$ \\
\hline $\mathrm{C} 10 \mathrm{C} 11$ & $1.364(6)$ & $\mathrm{C} 8 \mathrm{C} 9 \mathrm{O} 2$ & $117.0(3)$ & O1 Sn1 C10 & $86.79(10)$ \\
\hline C10 C15 & $1.386(5)$ & $\mathrm{O} 1 \mathrm{C} 9 \mathrm{O} 2$ & $123.0(3)$ & $\mathrm{O} 2 \mathrm{Sn} 1 \mathrm{C} 10$ & $85.55(10)$ \\
\hline C10 Sn1 & $2.127(3)$ & $\mathrm{C} 11 \mathrm{C} 10 \mathrm{C} 15$ & $118.2(4)$ & O1 Sn1 C16 & $90.82(10)$ \\
\hline $\mathrm{C} 11 \mathrm{C} 12$ & $1.402(7)$ & C11 C10 Sn1 & $120.4(3)$ & O2 Sn1 C16 & $92.31(11)$ \\
\hline $\mathrm{C} 12 \mathrm{C} 13$ & $1.380(11)$ & C15 C10 Sn1 & $121.4(3)$ & & \\
\hline C13 C14 & $1.335(11)$ & C10 C11 C12 & $120.8(6)$ & & \\
\hline C14 C15 & $1.388(6)$ & C11 C12 C13 & $119.2(6)$ & & \\
\hline $\mathrm{C} 16 \mathrm{C} 17$ & $1.374(5)$ & $\mathrm{C} 12 \mathrm{C} 13 \mathrm{C} 14$ & $120.8(5)$ & & \\
\hline C16 C21 & $1.380(5)$ & C13 C14 C15 & $120.0(6)$ & & \\
\hline C16 Sn1 & $2.124(3)$ & C14 C15 C10 & $121.1(5)$ & & \\
\hline C17 C18 & $1.386(6)$ & C17 C16 C21 & $117.9(3)$ & & \\
\hline C18 C19 & $1.353(7)$ & C17 C16 Sn1 & $120.1(2)$ & & \\
\hline C19 C20 & $1.354(7)$ & C21 C16 Sn1 & $122.0(2)$ & & \\
\hline C20 C21 & $1.397(6)$ & C16 C17 C18 & $120.9(4)$ & & \\
\hline $\mathrm{C} 22 \mathrm{C} 23$ & $1.376(5)$ & C17 C18 C19 & $120.6(4)$ & & \\
\hline $\mathrm{C} 22 \mathrm{C} 27$ & $1.387(5)$ & C18 C19 C20 & $119.6(4)$ & & \\
\hline C22 Sn1 & $2.121(3)$ & C19 C20 C21 & $120.5(4)$ & & \\
\hline $\mathrm{C} 23 \mathrm{C} 24$ & $1.387(6)$ & C20 C21 C16 & $120.3(4)$ & & \\
\hline $\mathrm{C} 24 \mathrm{C} 25$ & $1.361(8)$ & $\mathrm{C} 23 \mathrm{C} 22 \mathrm{C} 27$ & $117.8(3)$ & & \\
\hline $\mathrm{C} 25 \mathrm{C} 26$ & $1.356(8)$ & C23 C22 Sn1 & $121.2(3)$ & & \\
\hline $\mathrm{C} 26 \mathrm{C} 27$ & $1.383(6)$ & C27 C22 Sn1 & $121.0(2)$ & & \\
\hline O1 Sn1 & $2.275(2)$ & $\mathrm{C} 22 \mathrm{C} 23 \mathrm{C} 24$ & $120.8(4)$ & & \\
\hline $\mathrm{O} 2 \mathrm{Sn} 1$ & $2.230(2)$ & $\mathrm{C} 23 \mathrm{C} 24 \mathrm{C} 25$ & $120.3(5)$ & & \\
\hline
\end{tabular}




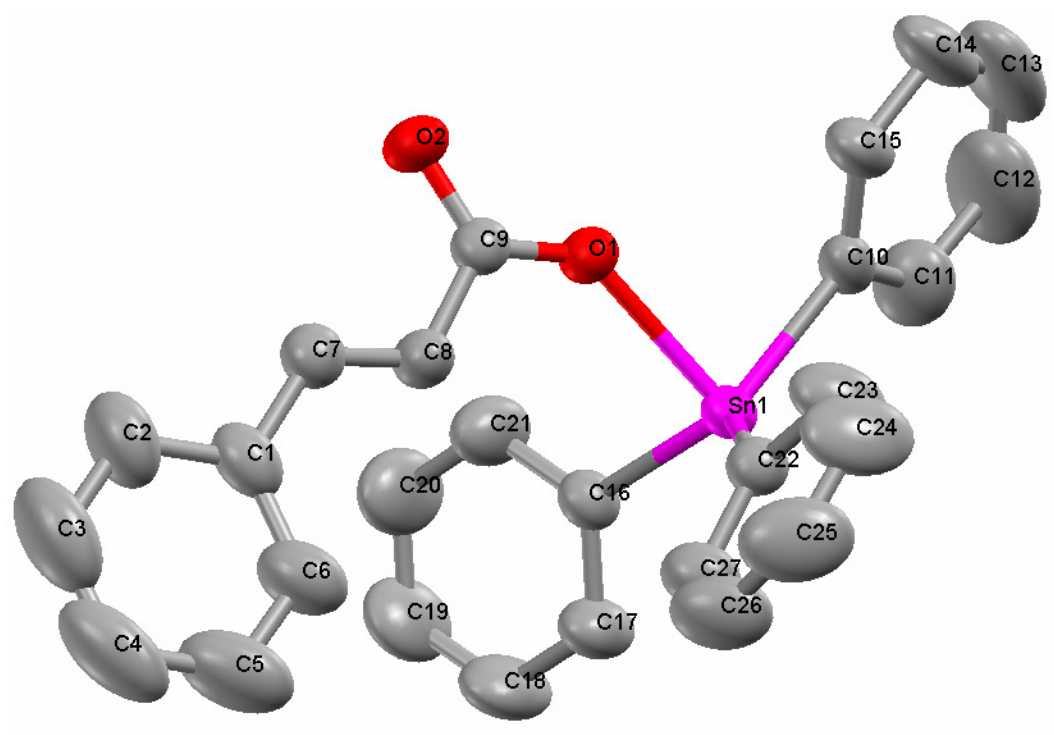

Figure 1. ORTEP diagram of compound 1, showing the atom-numbering scheme and displacements ellipsoids at the $50 \%$ probability, hydrogen atoms are omitted for clarity.

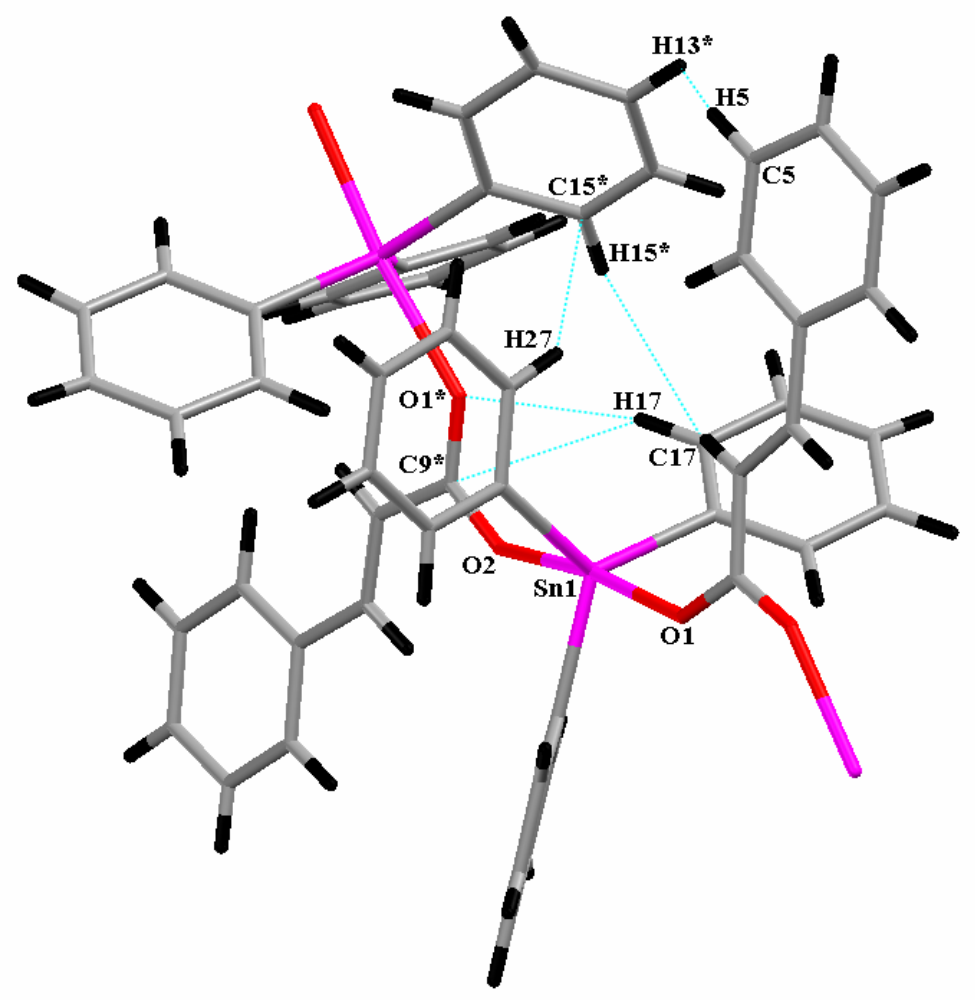

Figure 2. Non-classical intramolecular interactions. The marked atoms are at the symmetry positions: * 1.5-x,1/2+y, 1/2-z. 
Figure 3 shows two $\mathrm{C}-\mathrm{H} \cdots \pi$ intermolecular interactions, that connect two different polymer lines, those interactions are considered as strong hydrogen bonds ${ }^{15}$, because the short distances and angles $(\mathrm{C} 26-\mathrm{H} 26 \cdots \mathrm{C} 17)=146.17$ and $(\mathrm{C} 26-\mathrm{H} 26 \cdots \mathrm{C} 17)=162.49$; in both cases $\mathrm{C}-\mathrm{H} \cdots \pi$ acts as a $\mathrm{C}-\mathrm{H}$ (guest) $/ \pi$ (host) interaction ${ }^{16}$. All such interactions are important because they contribute that the molecule $\mathbf{1}$ stays in a supramolecular polymeric structure.

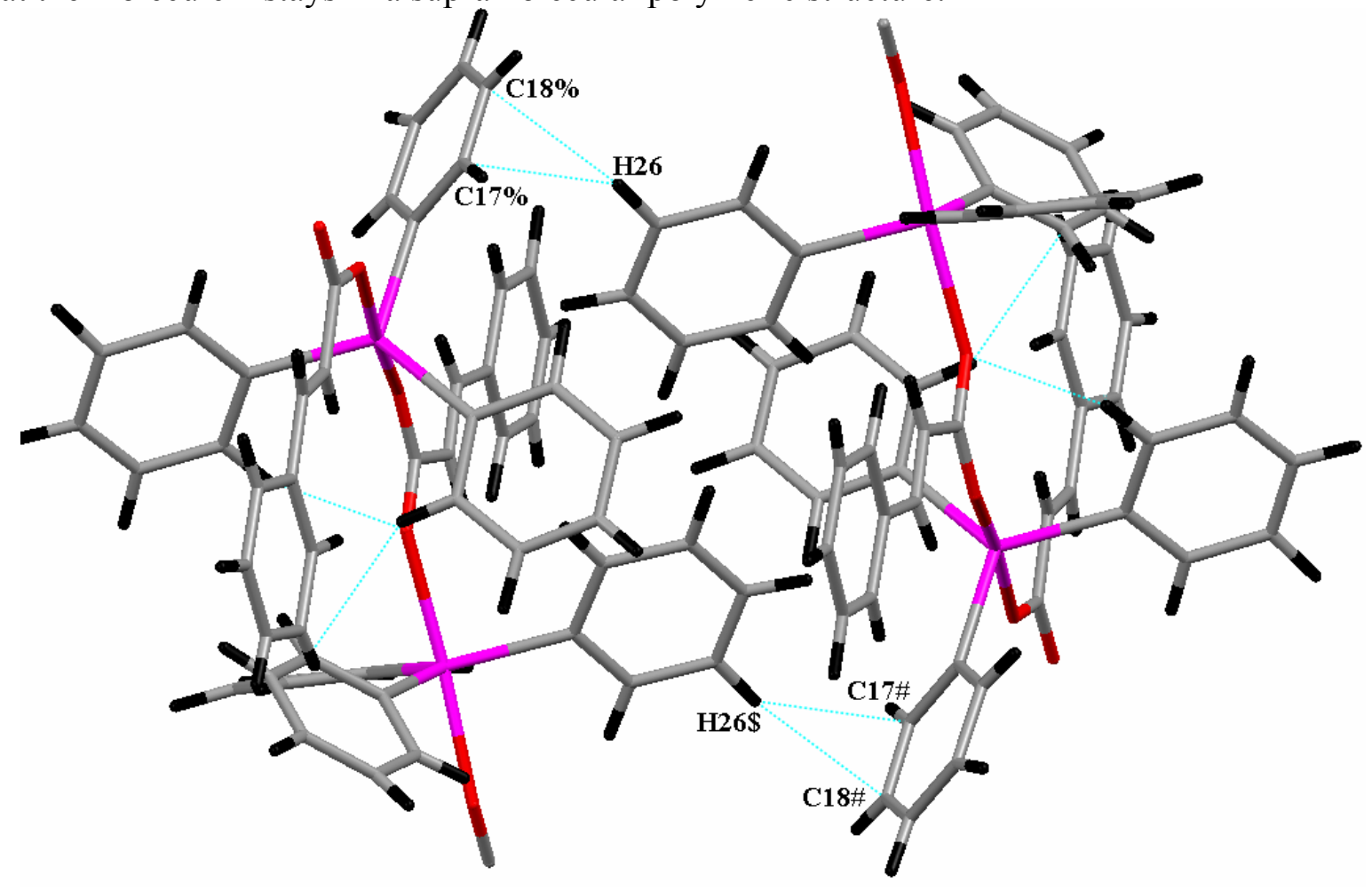

Figure 3. Non-classical intermolecular interactions. The marked atoms are at the symmetry positions: (\%) $1 / 2+\mathrm{x}, 1 / 2-\mathrm{y}, 1 / 2+\mathrm{z}$; (\$) $2-\mathrm{x},-\mathrm{y}, 1-\mathrm{z}$; (\#) $1.5-\mathrm{x},-1 / 2+\mathrm{y}, 1 / 2-\mathrm{z}$. 


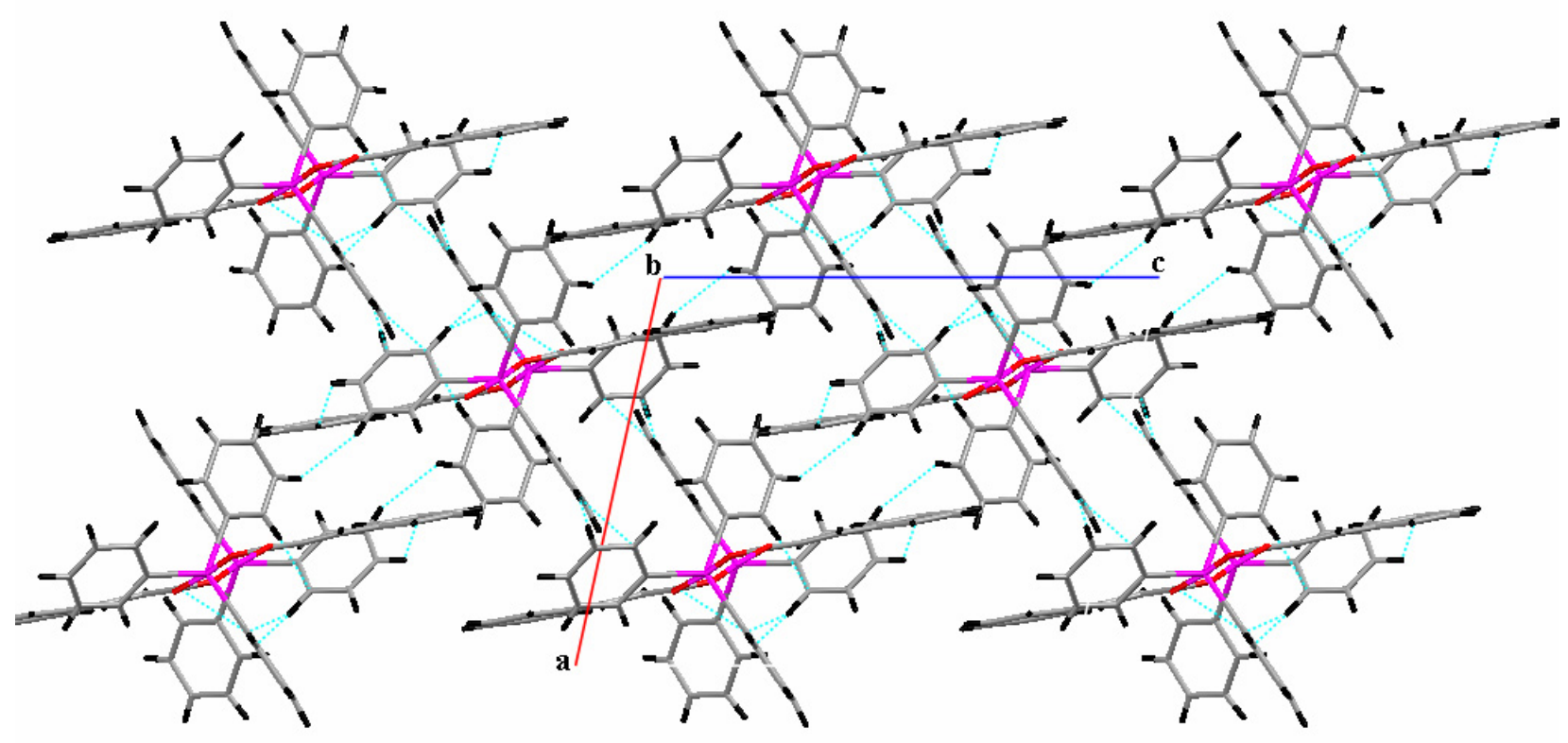

Figure 4. Supramolecular structure of compound 1, packing is controlled by non-classical interactions, view along $b$ exe.

Table 5. Hydrogen contacts geometry $(\AA)$ for 1

\begin{tabular}{|c|c|c|c|c|c|c|}
\hline$\#$ & Atom 1 & Atom 2 & Symm. op. 1 & Symm. op. 2 & Length & Length-VdW \\
\hline 1 & $\mathrm{C} 17$ & $\mathrm{H} 15^{*}$ & $\mathrm{x}, \mathrm{y}, \mathrm{z}$ & $1.5-\mathrm{x}, 1 / 2+\mathrm{y}, 1 / 2-\mathrm{z}$ & 2.819 & -0.081 \\
\hline 2 & H5 & $\mathrm{H} 13^{*}$ & $\mathrm{x}, \mathrm{y}, \mathrm{z}$ & $1.5-\mathrm{x}, 1 / 2+\mathrm{y}, 1 / 2-\mathrm{z}$ & 2.389 & -0.011 \\
\hline 3 & H17 & C9* & $\mathrm{x}, \mathrm{y}, \mathrm{z}$ & $1.5-\mathrm{x}, 1 / 2+\mathrm{y}, 1 / 2-\mathrm{z}$ & 2.812 & -0.088 \\
\hline 4 & H17 & $\mathrm{O} 1 *$ & $\mathrm{x}, \mathrm{y}, \mathrm{z}$ & $1.5-\mathrm{x}, 1 / 2+\mathrm{y}, 1 / 2-\mathrm{z}$ & 2.557 & -0.163 \\
\hline 5 & $\mathrm{H} 27$ & $\mathrm{C} 15^{*}$ & $\mathrm{x}, \mathrm{y}, \mathrm{z}$ & $1.5-\mathrm{x}, 1 / 2+\mathrm{y}, 1 / 2-\mathrm{z}$ & 2.896 & -0.004 \\
\hline 6 & $\mathrm{H} 26$ & $\mathrm{C} 17 \%$ & $\mathrm{x}, \mathrm{y}, \mathrm{z}$ & $1 / 2+x, 1 / 2-y,-1 / 2+z$ & 2.789 & -0.111 \\
\hline 7 & $\mathrm{H} 26$ & $\mathrm{C} 18 \%$ & $\mathrm{x}, \mathrm{y}, \mathrm{z}$ & $1 / 2+x, 1 / 2-y,-1 / 2+z$ & 2.694 & -0.206 \\
\hline 8 & $\mathrm{C} 17 \#$ & $\mathrm{H} 26 \$$ & $1.5-\mathrm{x},-1 / 2+\mathrm{y}, 1 / 2-\mathrm{z}$ & $2-x,-y, 1-z$ & 2.789 & -0.111 \\
\hline 9 & C18\# & $\mathrm{H} 26 \$$ & $1.5-\mathrm{x},-1 / 2+\mathrm{y}, 1 / 2-\mathrm{z}$ & $2-x,-y, 1-z$ & 2.694 & -0.206 \\
\hline
\end{tabular}

\section{Conclusions}

From spectroscopy data we found different tin compounds: for $\mathbf{1}$ (penta-coordinated, ${ }^{119} \mathrm{Sn}=$ 112.0), for 2 (tetra-coordinated, ${ }^{119} \mathrm{Sn}=+109.9$ ), for 3 (hexa-coordinated, ${ }^{119} \mathrm{Sn}=-260.2$ ) and for 4 (penta-coordinated ${ }^{119} \mathrm{Sn}=-20.0$ ). The structure of 1 was corroborated by X-ray diffraction, we found a polymeric triphenyltin-trans-cinnamete structure, because the acidity of tin center, causes that the carboxylic group in the trans-cinnamic acid acts as a bridge between two tin 
groups, the lattice are govern by non classical intra- and inter-molecular interactions (D-H $\cdots \pi)$. Compound 3 and $\mathbf{4}$ were obtained dissolving 1 and 2 in DMSO- $\mathrm{d}_{6}$, the chemical shift of ${ }^{119} \mathrm{Sn}$ shows signals at lower frequency than the starting materials, showing the acidity of the tin center.

\section{Acknowledgements}

Present work was supported financially by SEP-PROMEP (Grant 103.5/04/1322). A. P-H, We Thank Conacyt for scholarship, C. R. G.-T. as well as PROMEP, and Universidad de Colima that is acknowledged.

\section{Supplementary Information}

X-ray Crystallography data (excluding structure factors) for compound $\mathbf{1}$ have been deposited with the Cambridge Crystallographic Data Center: CCDC 651003. Complete copies may be obtained free of charge on application to the Director: Cambridge Crystallographic Data Centre, 12 Union Road, Cambridge CB2 1EZ, United Kingdom. For further information on submission to the CCDC consult their web site at www.ccdc.cam.ac.uk.

\section{Experimental Section}

General Procedures. trans-Cinnamic acid, triphenyltin chloride, tributhyltin chloride, triethylamine, benzene and DMSO- $\mathrm{d}_{6}$ were commercially available. The compounds $\mathbf{1}$ and $\mathbf{2}$ were performed using a Schlenk technique, with fresh distilled solvents and were stored at room temperature. Melting points were getting from Melt-Temp from capillaries, and are uncorrected. IR spectrum was recorded on an FT-IR 1600 Perkin Elmer spectrophotometer using solid compounds $\mathrm{KBr}$ pellets in the $4000-400 \mathrm{~cm}^{-1}$ range. Mass spectra in the $\mathrm{FAB}+$ technique was performed in a Jeol MStation 700 spectrometer of high resolution in the range of 1 to $5000 \mathrm{~m} / \mathrm{z}$. The elemental analyzes were performed in a Thermofinniga, Flash 112 under standard conditions. The NMR spectrums were obtained in $\mathrm{CDCl}_{3}$ and DMSO- $\mathrm{d}_{6}$ in the Bruker $300 \mathrm{MHz}$ and Jeol Eclipse $400 \mathrm{MHz}$ spectrometers. For ${ }^{1} \mathrm{H}(300.13185 \mathrm{MHz}$ or $399.78219 \mathrm{MHz})$, for ${ }^{13} \mathrm{C}$ $(75.47564 \mathrm{MHz}$ or $100.52530 \mathrm{MHz})$ using TMS as internal reference; and $\mathrm{Me}_{4} \mathrm{Sn}$ for ${ }^{119} \mathrm{Sn}$ (111.92607 MHz or 149.08124), respectively. ${ }^{17}$ Chemical Shifts $(\delta)$ are reported in ppm, the coupling constants ${ }^{n} \mathrm{~J}\left({ }^{13} \mathrm{C}-{ }^{19 / 117} \mathrm{Sn}\right)$ were got from the satellite signal in the ${ }^{13} \mathrm{C}$ spectrum, the values are reported in Hertz $(\mathrm{Hz})$. X-ray diffraction for compound 1 was performed with Enraf Nonius FR590 Kappa CCD $\left(\lambda_{\mathrm{MoK} \alpha}=0.71073 \AA\right)$ the crystals were mounted in a fiver glass. Relevant crystallographic data are summarized in table 3 , structure solution and refinement were 
performed in Crystals $^{18}$ program. Graphics were performed in ORTEP ${ }^{19}$ and Mercury $^{20}$ programs.

Triphenyltin-trans-cinnamate $\mathbf{1}\left[\left(\mathbf{C}_{9} \mathbf{H}_{7} \mathbf{O}_{2}\right) \mathbf{S n}\left(\mathbf{C}_{6} \mathbf{H}_{5}\right)_{3}\right]$. A solution of $0.5 \mathrm{~g}(3.3 \mathrm{mmol})$ of $\mathbf{I}$ and $0.4702 \mathrm{ml}(0.3414 \mathrm{gr}, 3.374 \mathrm{mmol})$ of triethylamine in $20 \mathrm{ml}$ of benzene was prepared under continue stirring. A separated solution was prepared by addition of $1.2515 \mathrm{gr}(3.3 \mathrm{mmol})$ triphenyltin chloride and $0.4702 \mathrm{ml}(0.3414 \mathrm{gr}, 3.374 \mathrm{mmol})$ of triethylamine in $20 \mathrm{ml}$ of benzene. Then the solutions were mixed under strong and continue stirring, the reaction mixture was refluxed by $3 \mathrm{~h}$ after that the solution was stirred by $3 \mathrm{~h}$ at room temperature. The mixture of reaction was filtered off and the solvent was removed at low pressure, the white solid was washed two times with benzene and was crystallized with chloroform. The white solid, $1.58 \mathrm{~g}$ (94 \%), pf = 133-135 C, IR (solid): 1385.3 ( $\mathrm{C}=\mathrm{O}$ sym), 1499.9( $\mathrm{C}=\mathrm{O}$ asym), $1499(-\mathrm{C}=\mathrm{C}-), 1636$ $(-\mathrm{C}=\mathrm{N}-),(-\mathrm{C}-\mathrm{Sn}-),(-\mathrm{C}-\mathrm{S}-),(-\mathrm{S}=\mathrm{C}-) . \mathbf{N M R}\left(\mathrm{CDCl}_{3}\right):{ }^{119} \mathrm{Sn}:-112.0 .{ }^{1} \mathbf{H}: \mathrm{H} 2(7.92), \mathrm{H} 3(7.55)$, H4(7.54), H5(7.55), H6(7.92), H7(6.65), H8(7.81), H1 1(7.44), H12(7.41), H13(7.40), H14(7.41), H15(7.44). ${ }^{13} \mathrm{C}: \mathrm{C} 1(135.0), \mathrm{C} 2(129.9), \mathrm{C} 3(128.4), \mathrm{C} 4(128.8), \mathrm{C} 5(128.4), \mathrm{C} 6(129.9), \mathrm{C} 7(119.7)$, C8(144.7), $\quad \mathrm{C} 9(173.4), \quad \mathrm{C} 10(138.9,[48.1]), \quad \mathrm{C} 11(136.9), \quad \mathrm{C} 12(128.9,[63.3]), \quad \mathrm{C} 13(130.1)$, C14(128.9), C15(136.9). e/m (FAB+): $267\left(\mathrm{C}_{9} \mathrm{H}_{7} \mathrm{O}_{2} \mathrm{Sn}, 10 \%\right), 351\left(\mathrm{C}_{18} \mathrm{H}_{15} \mathrm{Sn}, 100 \%\right), 421$ $\left(\mathrm{C}_{21} \mathrm{H}_{17} \mathrm{O}_{2} \mathrm{Sn}, 93 \%\right), 497\left(\mathrm{C}_{27} \mathrm{H}_{2} \mathrm{O}_{2} \mathrm{Sn}, 5\right.$ \%). Anal. Calc. for $\mathrm{C}_{27} \mathrm{H}_{22} \mathrm{O}_{2} \mathrm{Sn}$ : C, 65.23; H, 4.46. Found: C, 64.88; H, 4.51.

Tributyltin-trans-cinnamate $2\left[\left(\mathrm{C}_{9} \mathrm{H}_{7} \mathrm{O}_{2}\right) \mathrm{Sn}\left(\mathrm{C}_{4} \mathrm{H}_{9}\right)_{3}\right]$. Using the same procedure described for compound 1, a solution of $0.5 \mathrm{~g}(3.3 \mathrm{mmol})$ of $\mathbf{I}$ and $0.4702 \mathrm{ml}(0.3414 \mathrm{gr}, 3.3 \mathrm{mmol})$ of triethylamine in $20 \mathrm{ml}$ was mixed with a separated solution of $0.9151 \mathrm{ml}(1.0982 \mathrm{gr}, 3.3 \mathrm{mmol})$ tributhyltin chloride and $0.4702 \mathrm{ml}(0.3414 \mathrm{gr}, 3.374 \mathrm{mmol})$ of triethylamine in $20 \mathrm{ml}$ of benzene to produced a white solid $1.37 \mathrm{~g}(93 \%), \mathrm{pf}=65-69 \mathrm{C}$. IR (solid): $1386(\mathrm{C}=\mathrm{O}$ sym), 1542.5 $(\mathrm{C}=\mathrm{O}$ asym $), 1542(-\mathrm{C}=\mathrm{C}-), 1640(-\mathrm{C}=\mathrm{N}-),(-\mathrm{C}-\mathrm{Sn}-),(-\mathrm{C}-\mathrm{S}-),(-\mathrm{S}=\mathrm{C}-) . \mathbf{N M R}\left(\mathrm{CDCl}_{3}\right):{ }^{119} \mathrm{Sn}$ NMR: + 110.9. ${ }^{1}$ H NMR: H2(7.43), H3(7.27), H4(7.27), H5(7.27), H6(7.43), H7(6.44), H8(7.55), H10(1.25), H11(1.57), H12(1.25), H13(0.84). ${ }^{13}$ C NMR: C1(137.2), C2(128), $\mathrm{C} 3(128.8), \quad \mathrm{C} 4(129.8), \quad \mathrm{C} 5(128.8), \quad \mathrm{C} 6(128.0), \quad \mathrm{C} 7(120.4), \quad \mathrm{C} 8(143.7), \quad \mathrm{C} 9(172.2)$, C10(16.9,[ 351.9]), $\mathrm{C} 11(28.16,[19.8]), \quad \mathrm{C} 12(27.0,[67.2]), \quad \mathrm{C} 13(13.99) . \quad \mathbf{e} / \mathbf{m} \quad(\mathrm{FAB}+): 291$ $\left(\mathrm{C}_{12} \mathrm{H}_{9} \mathrm{Sn}, 30 \%\right), 381\left(\mathrm{C}_{17} \mathrm{H}_{25} \mathrm{O}_{2} \mathrm{Sn}, 100 \%\right), 439\left(\mathrm{C}_{21} \mathrm{H}_{34} \mathrm{O}_{2} \mathrm{Sn}, 5 \%\right), 727\left(\mathrm{C}_{33} \mathrm{H}_{25} \mathrm{O}_{2} \mathrm{Sn}_{2}, 28 \%\right)$, $817\left(\mathrm{C}_{42} \mathrm{H}_{32} \mathrm{O}_{4} \mathrm{Sn}_{2}, 15 \%\right)$. Anal. Calc. for $\mathrm{C}_{21} \mathrm{H}_{34} \mathrm{O}_{2} \mathrm{Sn}: \mathrm{C}, 57.69 ; \mathrm{H}, 7.84$. Found: C, 57.88; H, 8.59 .

Compounds $3\left[\left(\mathrm{C}_{9} \mathrm{H}_{7} \mathrm{O}_{2}\right)\left(\mathrm{DMSO}-\mathrm{d}_{6}\right) \cdot \mathbf{S n}\left(\mathrm{C}_{6} \mathrm{H}_{5}\right)_{3}\right]$ and $4\left[\left(\mathrm{C}_{9} \mathrm{H}_{7} \mathrm{O}_{2}\right)\left(\mathrm{DMSO}-\mathbf{d}_{6}\right) \cdot \mathbf{S n}\left(\mathrm{C}_{4} \mathrm{H}_{9}\right)_{3}\right]$ were analyzed dissolving them in DMSO- $\mathrm{d}_{6}$. 


\section{References}

1. (a) Dewick, P. M. Nat. Prod. Rep. 1998, 15, 17. (b) Trease, E. Origen y Transformación de Ácidos Cinámicos: Farmacogonosia, México, 1991; pp 335-336.

2. (a) Lee, S.; Han, J. M.; Kim, H.; Kim, E.; Jeong, T. S.; Lee, W. S.; Cho, K. H. Bioorg. Med. Chem. Letters 2004, 14, 4677. (b) Narasimhan, B.; Belsare, D.; Pharande, D.; Mourya, V.; Dhake, A. Eur. J. Med. Chem. 2004, 30, 827. (c) Camire, M. E.; Dougherty, M. P.; Briggs, J. L. Cereal Chem. 2005, 826, 666. (d) Sheng, Y. W.; Yueh, H. K.; Hsing, N. C.; Pie-Ling, K.; Hsin-Sheng, T.; Ku-Feng L.; Ning-Sun Y.; Lie-Fen, S. J. Agric. Food Chem. 2002, 50, 1859 .

3. Piper, N.; Klaus-Mrestani, C.; Schürmann, M.; Jurkschat, K.; Biesemants, M.; Verbrueggen, I.; Martins J. C.; Willem, R. Organometallics 1997, 16, 1043.

4. (a) Keppler, B. H. Metal Complexes in Cancer Chemotherapy; VCH: Weinheim. (b) Gielen, M. Tin Based Anti-tumor Drugs, Springer-Verlag: Berlin, 1990. (c) Davies, A. G.; Smith, P. J.; Wilkinson, G. Comprehensive Organometallic Chemistry, Pergamon Press: New York, 1982; p 519.

5. Jain, M.; Maanju, S.; Singh, R. V. Appl. Organometal. Chem. 2004, 18, 471.

6. (a) Gielen, M. J. Braz. Chem. Soc. 2003, 14, 870. (b) Gielen, M.; Dalil, H.; Ghys, L.; Boduszek, B.; Tiekink, E. R. T.; Martins, J. C.; Biesemans, M.; Willem, R. Organometallics 1998, 17, 4259.

7. (a) Wrackmeyer, B. Annu. Rep. Spectrosc. 1999, 38, 201. (b) Wrackmeyer, B. Annu. Rep. Spectrosc. 1985, 16, 73.

8. Davies, A. G.; Harrison, P. G.; Kennedy, J. D.; Mitchell, T. N. Puddephatt, R. J.; McFarlane, W. J. Chem. Soc. (C) 1969, 1136.

9. Tupčiauskas, A. P.; Sergeyev, N. M.; Ustynyuk, Yu. A. Liet. Fiz. Rink. 1971, 11, 93.

10. Danush, M.; Ali, S.; Mazhar, M.; Badshah, A.; Choudhary, M. I.; Alt, H. G.; Kehr, G. Polyhedron 1995, 14, 3115.

11. Holeček, M.; Nádvornik, M.; Handlír, K.; Lyčka, A. J. Organomet. Chem. 1983, 241, 177.

12. Lyčka, A.; Šnobl, D.; Handlír, K.; Holeček, J.; Nádvrník, M. Collect. Czech. Chem. Commun. 1981, 46, 1383.

13. (a) Jimenez-Pérez, V. M.; Camacho-camacho, C.; Güizado-Rodríguez, M.; Nöth, H.; Contreras, R. J. Organomet. Chem. 2000, 614, 283. (b) Contreras, R.; Jímenez-Pérez, V. M.; Camacho-Camacho, C.; Güisado-Rodríguez, M.; Wrackmeyer, B. J. Organometallic. Chem. 2000, 604, 229. (c) Camacho-Camacho, C.; Jímenez-Pérez, V. M.; Galvez-Ruiz, J. C.; Flores-Parra, A.; Contreras, R. J. Organometallic. Chem. 2006, 691, 1590.

14. (a) Nishio, M., Cryst. Eng. Comm. 2004, 6, 130. (b) Taylor, R.; Kennard, O. J. Am. Chem. Soc. 1982, 104, 5063. (c) Steiner, T. Angew. Chem. Int. Ed. 2002, 41, 48. (d) Steiner, T. J. Phys. Chem. A 1998, 102, 7041.

15. Chowdhury, S. K.; Joshi, V. S.; Samuel, A. G.; Puranik, V. G.; Tavale, S. S.; Sarkar, A. Organometallics 1994, 13, 4092. 
16. Madhavi, N. N. L.; Katz, A. M.; Carrell, H. L.; Nangia, A.; Desiraju, G. R. Chem. Commun. 1997, 1953.

17. Harris R. K.; Becker, E. D.; Cabral de Menezes, S. M.; Goodfellow, R.; Granger, P. Magn. Reson. Chem. 2002, 40, 489.

18. (a) Betteridge, P. W.; Carruthers, J. R.; Cooper, R. I.; Prout, K.; Watkin, D. J. J. Appl. Cryst. 2003, 36, 1487. (b) Watkin, D. J.; Prout, C. K.; Pearce, L. J. CAMERON, Chemical Crystallography Laboratory, University of Oxford: Oxford, 1996. (c) Watkin, D. J.; Prout, C. K.; Lilley, P. M. de Q. RC93, Chemical Crystallography Laboratory, University of Oxford: Oxford. 1994.

19. Farrugia, L. J. J. Appl. Cryst. 1997, 30, 565.

20. Mercury 1.4.2., Cambridge Crystallographic Data Centre, 2006, http://www.ccdc.cam.ac.uk/ 